\title{
Strengthening the Character of Independence through Learning Citizenship Education in Networks During the Covid-19 Pandemic
}

\author{
Dina Naseha Kadaria ${ }^{1}$, Mukhamad Murdiono ${ }^{2}$ \\ \{dinanaseha.2019@student.uny.ac.id\} \\ Yogyakarta State University-Jl. Colombo No. 1, Sleman, Yogyakarta 55281
}

\begin{abstract}
The COVID-19 pandemic has changed various aspects of human life today, especially in the world of education. This requires all elements of education to adapt and continue learning online, especially in PPKn learning. The purpose of this study is to provide an overview of online-based PPKn learning in fostering independent character during the COVID-19 pandemic at Yasmida Ambarawa Middle School. Online learning is an effective solution to reviving classrooms even though learning is not carried out typically, as is usually the case considering the time and place to be at risk during this pandemic. However, it is essential to evaluate this PPKn learning technique according to local conditions. Online learning does not necessarily have adverse effects however, are also positive sides. This is in terms of the independence of students in participating in online-based CPC learning in schools. This study uses a descriptive method with a qualitative approach which, will be reviewed from how to foster an independent character in the Covid-19 pandemic era at Yasmida Ambarawa Middle School.
\end{abstract}

Keywords: online learning, independent character, pandemic COVID-19

\section{Introduction}

Coronavirus Disease 2019, also known as COVID-19, has infected millions of people in over 200 countries and caused widespread devastation. The disease, caused by the Severe Acute Respiratory Syndrome Coronavirus 2 or SARS-CoV-2, was first diagnosed on December 31, 2019 in Wuhan, Hubei Province, China, with unexplained pneumonia (Lee, 2020). This case was brought on by the Coronavirus, also known as the COVID-19 is a virus that infects people (Corona Virus Disease-2019). The rapidity with which this virus spreads is one of its characteristics. Based on WHO data, it was found that COVID-19 has become a global pandemic with 29,500,000 confirmed positive cases in 216 countries worldwide (Update: 16-05-2021). Since early March, the Coronavirus has ravaged Indonesia, with 2.120, 000 confirmed positive cases scattered throughout 34 provinces and 415 districts/cities as of September 16, 2020. (Task Force for the Acceleration of Handling COVID-19 Indonesia, 2021). The impact of the COVID-19 pandemic on 
several facets of human life has changed, including the current state of schooling. as well as education (Ustin et al, 2016).

In most nations, the situation induced by covid-19 has resulted in the curtailment of activities at all levels of education, forcing residents to retreat to their homes (Faura: 2020). The COVID-19 epidemic necessitates distance learning, which has never been done at the same time. (Sun et al., 2020) for all aspects of education, including students, teachers, and parents. During the COVID-19 epidemic, there were practically universal online learning tendencies (Goldschmidt \& Msn, 2020). This is enforced so that all Indonesians can decrease their interactions with one another and maintain a safe distance ( Agustino, 2020; Ahidin. 2020) for all aspects of education, including students, teachers, and parents. During the COVID-19 epidemic, there were practically universal online learning tendencies (Goldschmidt \& Msn, 2020). This is enforced so that all Indonesians can decrease their interactions with one another and maintain a safe distance (Agustino, 2020; Ahidin. 2020), one of which is the disciplined personality. According to this definition, a person with character is someone who strives to improve himself as an individual, as a member of society, as a religious creature, and in connecting with nature. Character is a system for communicating character ideals to the community in general and to students in particular Character education.

The government is responsible for instilling national character values, but all parties, especially formal educational institutions that play a larger role in education, are equally responsible. Given the importance of character development in children, there is a need for character education that is done correctly and responsibly in light of present circumstances. given the current situation Furthermore, educational institutions, particularly schools, are viewed as critical sites for shaping character.

Even if educators and learners are in separate locations, online learning is effective for implementing learning. This may be a solution to the problem of pupils' slow learning. According to Faura (2020), the demands of students with social difficulties or who are in a perilous scenario, such as at this moment, must be met by doing research. Prevention, evaluation, intervention, and follow-up are all part of the process, which is coordinated with educational and community resources. Teachers, students, and parents, on the other hand, have numerous challenges in learning PPKN subjects that are conducted online.

Given SMP Yasmida Ambarawa's location, which is remote from urban regions where the network is difficult to detect, as well as other challenges, By examining the current state of online learning, such as whether online learning, particularly at SMP Yasmida Ambarawa Pringsewu Lampung, can guarantee the formation of an independent character, a number of questions arise, such as whether online learning, particularly at SMP Yasmida Ambarawa Pringsewu Lampung, can guarantee the formation of an independent character ? However, in a pandemic like the one we're in today, online PPKn learning is thought to be quite useful. One of them is the development of a self-sufficient personality. Students must be able to complete school tasks and study material on their own at home. Students confront a variety of challenges when carrying out individual work, one of which is difficult to comprehend. Another barrier to online learning is that students are often affected by laziness, causing assignments to be neglected. As a result, teachers must take an active part and fully implement online learning. During this pandemic, students' independence cannot be denied, and the home setting and family environment also have an impact on online 
learning performance. The sound of a crowded and noisy house makes it difficult for students to comprehend and absorb the teacher's information.

\section{Research Methods}

This research employs a descriptive strategy in conjunction with a qualitative approach. In the Covid-19 Pandemic Era, this article shows how Online-based PPKn Learning can help Yasmida Ambarawa Middle School cultivate an autonomous character. This study took place in SMP Yasmida Ambarawa in Lampung's Pringsewu Regency. This study was carried out in the midst of the Covid-19 pandemic that is currently ravaging the homeland As a result, it was done remotely via an internet technique. The study's research topic was chosen with care, and it was tailored to the study's aims (Sugiyono, 2013: 301).

Teachers of Pancasila and civic education, school principals, and students participated in the study. The data for this study was gathered through interviews and documentation. Primary and secondary data sources were used in this study. The primary data source for this study was data from interviews with informants at Yasmida Ambarawa Middle School, including school principals and PPKn teachers. The participants in this study were eighth-grade students at SMP Yasmida Ambarawa.

\section{Results and Discussion}

Strategy social removing or physical separating To utilize Limiting the spread of Coronavirus energizes all components of instruction to actuate classes despite the fact that schools are shut. Shutting schools is the best moderation measure to limit the spread of the plague to youngsters. The arrangement offered is to carry out learning at home by using different supporting offices.

During the Coronavirus pandemic, learning at home or online is an answer for proceeding with the semester, particularly in the PPKn subject, which requires kids consistently to be autonomous. Web based learning is characterized as an information move experience utilizing video, sound, pictures, text correspondence, programming (Basilaia and Kvavadze, 2020), and web network support (Zhu and Liu, 2020).

Offices that help free internet learning through different conversation rooms, for example, Classroom, Whatsapp, Smart Class, Zenius, Quipper and Microsoft (Abidah et al., 2020). Whatsapp highlights incorporate Whatsapp Gathering, which can send instant messages, video pictures, and documents in different configurations to all individuals (Kusuma and Hamidah, 2020). Google Study hall likewise permits instructors and educators to foster inventive learning than the school site. Today, numerous schools are effectively acting by making free advancements by making learning support media in the time of the Coronavirus pandemic.

Based on interviews conducted with resource persons, namely teachers of Pancasila and citizenship education subjects of SMP Yasmida Ambarawa, coded A1, information was obtained

that the school implements online learning using school web media specifically designed to make 
it easier for students to receive material or as a means of assessment or assessment. For final assessments such as UTS or UAS, the school uses offline media using students going to school but only to take question sheets from Pancasila and citizenship education teachers for the next process to be carried out using online media again. This is done by the school because, according to B1, the school feels important for teachers and students to meet occasionally. Besides that the question sheets given by students can make it easier for the assessment process because the results will be in the form of a photo of the question sheet, which is named along with the students' answers. , this is also done to minimize cheating. And According to the resource person A1 in the era of the Covid-19 pandemic, it is very good and effective in implementing an independent character because students are obliged and required to always be accustomed to working on their own at home, with this long process, according to him the independent character will be attached to students then become the character of students the. The school completely upholds this internet learning action for ordinary wellbeing.

Individual B's asset also discovered that the shrewdness underlying the Coronavirus flare-up could act on children's individuals, specifically autonomous individuals, but remember to always keep up with the advancement of understudies in internet comprehension so that qualities are not harmed. Pancasila's worth and character are not forgotten, and the school expects instructors to play an active role in all learning activities, Especially when it comes to learning Pancasila and community training. Educators should deal with their activities in arranging with the multi-skilled and instructional direction group, evaluating the demand and most appropriate mediation modalities for each circumstance. (2020, Faura) However, to ensure that the features and characteristics of Pancasila are not lost, the school requires that instructors have an active role in all learning, particularly in learning Pancasila and urban training. Here, instructors should organize their actions with the multi-skilled and instructive direction group, surveying for each situation the need and most fitting mediation modalities (Faura: 2020) however remember to consistently go with the advancement of understudies in web based realizing so the qualities and characters of Pancasila are not lost, the school requests educators to assume a functioning part in all learning, particularly in learning Pancasila and urban training. Instructors here should deal with their activities in planning with the multi-proficient and instructive direction group, surveying for each situation the need and most suitable mediation modalities (Faura: 2020)

Eye to eye conversations and information move resemble meeting through different free video chat video stages like Zoom and Google Meet. The stage permits instructors and understudies to meet and communicate basically with text offices and show exercises (Wiranda and Adri, 2019). These different administrations can be utilized to help the exchange of information to conversations in regards to learning content. This is additionally done by using all nearby assets broadly, for example, TV slots for schooling (Zhou et al., 2020). In Indonesia, TV on the TVRI channel is utilized to communicate instructive substance broadly. The substance broadcast is arranged dependent fair and square of schooling as per the educational plan in Indonesia.

Media for online learning is used at Yasmida Ambarawa Middle School using the school website, namely and using group whatsApp and other media such as google classroom. In online learning, there are many obstacles faced by teachers, especially PPKn teachers subjects. According to source A1, the obstacles in online learning are related to the signal network because $70 \%$ of Yasmida Ambarawa Middle School students live far from cities so that it is difficult to get a signal network. teachers must be required to be patient and always do the best In online learning, 
teachers face many obstacles, especially PPkn subjects. According to source A1, the obstacles in online learning are related to the signal network because $70 \%$ of Yasmida Ambarawa Middle School students live far from cities so that it is difficult to get a signal network. So that teachers must be patient and always do the best In online learning, there are many obstacles faced by teachers, especially teachers in Pancasila and civics education subjects. According to source A1, online learning is related to the signal network because $70 \%$ of Yasmida Ambarawa Middle School students live far from cities, it is difficult to get a signal network. So those teachers are required to be patient and always do their best.

Another obstacle or other constraint in online learning, according to resource person B1, is related to data packages (internet quota). The school once provided a free quota of 20GB to students, but it was only given two times due to school funds constraints. The results of the interviews conducted with $\mathrm{C} 1$ showed that initially, there were learning difficulties in online learning because learning was ineffective because it was only done on virtual media. Moreover, there is confusion among students in doing their tasks. However, this has become a habit for students to always be independent explore the material. Students have more time at home with their families todevelop an independent character through homework borne by these students. Students independence can be seen in various aspects such as be to do assignments and study material on their own, being able to accommodate time, and being able to organize themselves in order to avoid feeling lazy and always actively accepting material independently. According to

\section{Online-based PPKn learning in fostering an independent character in the Covid-19 pandemic era}

Character is a unique personality possessed by a person informing mental, moral, and moral values with good character and full of responsibility (Hidaytullah. 2010: 14), (Wibowo. 2012: 73). The formation of independent character in students' souls, in essence, can be developed through solid discipline, enthusiasm in carrying out routines and being severe, based on mature religious values by promoting a spirit of togetherness that is full of compassion, simplicity, honesty and a spirit of sincerity (Mangun Budiyanto and Imam Machali. 2014: 108). There is a spirit that is accompanied by self-discipline in accomplishing something with a sense of responsibility for the love and awareness that exists within a person, resulting in the person being deemed to have a good character or personality.

The value of independence is very important to be applied today because if there is no independence of students, students will feel stressed by the pressures they face in line with Mahapatra and Sharma's research (2020) which states that students who are under high pressure are known to face normative stress the ongoing academic demands of the pandemic. The stress experienced by students can disturb and harm the students themselves The value of independence is very important to apply today because if there is no independence of students, students will feel stressed by the pressures they face in line with Mahapatra and Sharma's research (2020) which states that students who are under high pressure are known to face normative stresses. The ongoing academic demands of the pandemic. The stress experienced by students can disturb and harm the students themselves The value of independence is very important to be applied today because if there is no independence of students, students will feel stressed by the pressures they face in line with Mahapatra and Sharma's research (2020) which states that students who are under 
high pressure are known to face normative stress related to their ongoing academic demands at the time of the pandemic. The stress experienced by students can disturb and harm the students themselves student participants will feel stressed by the pressures they face in line with Mahapatra and Sharma's research (2020), which states that students who are under high pressure are known to face ongoing normative stress related to their academic demands that took place when the pandemic occurred. The stress experienced by students can disturb and harm the students themselves. Student participants will feel stressed by the pressures they face in line with Mahapatra and Sharma's research (2020), which states that students under high pressure are known to face ongoing normative stress related to their academic demands that took place when the pandemic occurred. The stress experienced by students can disturb and harm the students themselves

There are various characters in students. One of the important characters to improve is an independent character because instilling an independent character from an early age will form students independent and confident in facing difficulties. Menur Baba (2020), people who are accustomed to developing with themselves will easily complete lessons quickly and appreciate themselves more. Jossberger (2011: 22) in his research on independence, said that students who have independence would succeed in learning. Independent students will be able to plan, determine, and evaluate learning during theoretical and practical learning so that students are able to improve their learning performance and be able to achieve good learning achievements (Rochmah, 2015). Susanto in Rochmah (2015), explains that the success of a child is undergoing the education process is not determined by IQ (Intelligence Quotient). There are many factors that influence it, one of which is the student's independent character. Independent students will be able to develop and organize themselves so that the goals they want can be achieved.

Agus Wibowo (Kurniawan Syamsul, 2014: 31) characterizes character training as schooling that ingrains and creates honorable characters in understudies so they have these respectable characters, apply and practice in their lives, regardless of whether in the family, as citizenry and residents. The characters created by the Service of Public Instruction (2010: 9-10) are arranged into 18 characters. These characters comprise of of Religious, Honesty, Tolerance, Discipline, Hard Work, Creative, Independent, Democratic, Curiosity, National Spirit, Love the Fatherland, Respect for Achievement, Friendly / Communicative, Love Peace, Love to Read, Care for the Environment, Care Social, Responsibility.

In line with him (Parker. 2005: 226). Emotional independence that can control emotions, both in economic and intellectual independence as well as in social independence. (Sri Arfiah. 2017: 77). The attitude of independence in students will impact changes in attitudes, behavior, and personality under the demands and needs based on religion. (Yusutria. 2013: 158). So that independence is an attitude, action and behavior that will bring confidence in your ability to face a problem and not depend on other parties.

Based on eighteen values of strengthening character education, namely independent character. Anita Lie and Sarah Prasasti (2004: 2) suggest that independence is the ability to carried out daily activities or tasks on your own or with a little guidance, according to the stage of development. During this pandemic, student independence can be seen from how students can complete learning activities that were originally at home then must be carried out at home and how students can interpret this independent character according to Hanna Widjaja (Nandang Budiman, 2006: 84). to handle difficulties without requiring special assistance from others, aversion to being governed by 
others, ability to carry out activities alone. The concept of independence, according to Lerner (Nandang Budiman, 2006: 84), comprises the freedom to act, not relying on others, not being influenced by the environment, and being free to handle one's own needs.

This concept is in line with that put forward by Watson and Lindgren (Nandang Budiman, 2006: 84) that independence is the freedom to take initiatives, overcome obstacles, be persistent in business, and do everything by yourself without other people. Meanwhile, Knowles (Syamsul Kurniawan, 2013: 133) explains that students who learn independently should not rely on the assistance, supervision and direction of others, including teachers/instructors continuously.

Thusly it ought to be executed autonomously anyplace, remembering for schools. With the goal that understudies have their imagination and drive and can chip away at their own, alluding to the direction they get. Given that time, area and distance are presently huge issues (Kusuma and Hamidah, 2020). So that distance learning turns into an answer for defeat troubles in executing vis-à-vis learning. Covids are a huge group of infections that cause sickness going from gentle to extreme side effects. Something like two kinds of Covid known to cause sicknesses that can cause serious manifestations like Center East Respiratory Disorder (MERS) and Extreme Intense Respiratory Condition (SARS).

Normal signs and indications of Coronavirus contamination incorporate intense respiratory issues like fever, hack and windedness. The normal hatching period is 5-6 days with the longest brooding time of 14 days. (Yurianto, Ahmad, 2020) The spread of the Covid at first significantly affected the slow monetary world, however presently the effect is likewise being felt by the universe of schooling. The arrangements taken by numerous nations, including Indonesia, by shutting all instructive exercises have made the public authority and related organizations present an option instructive cycle for understudies and understudies who can't do instructive foundations' instructive interaction.

The public authority has spoke to work, study and love from home to lessen the quantity of patients presented to Coronavirus. Minister Nadiem Anwar Makarim gave Roundabout Letter Number 3 of 2020 to the Instruction Unit and Number 36962/MPK.A/HK/2020 concerning Execution of Training in the Covid Illness (Coronavirus) Crisis Period, so learning exercises are done online with regards to anticipation the spread of Covid infection (COVID0-19). (Minister of Education, 2020) With the rise of the Coronavirus pandemic, educating and learning exercises that were initially completed in schools have now become learning at home through on the web. Internet learning is completed by means and models of every one of the approaches set up by the school.

Web based learning can utilize advanced innovation, for example, google classrooms, study houses, zoom, video change, phone or live talk Tnd others. In any case, what should be done is the task of tasks through the checking of tutoring by the educator through the WhatsApp bunch so the youngsters eally learn. The instructor likewise telecommutes in a joint effort with guardians, either through video calls or photographs of youngsters' learning exercises at home to guarantee there is a cooperation between the educator and guardians. A few schools that have not had the option to coordinate web based instructing and learning exercises can foster educator imagination to exploit elective learning media as long as understudies learn at home.

They can utilize existing learning assets, specifically understudy books by the topics instructed by a foreordained timetable. Online-based learning shows consented to arrangements. According to Vicky and Putri, after participating in online learning-based learning, understudies 
are more enthusiastic about learning (Wicaksono and Rachmadyanti, 2016). The use of Google Homerooms in elementary schools while keeping traditional learning in mind.

This is a benefit of mixed realizing, which consolidates two traditional and web based learning techniques to cause understudies to feel good and dynamic in building their insight. The review led by Lenny N Rosalin, Deputy Minister of PPPA for the Child Development Sector, likewise showed kids' assumptions regarding the learning program at home. Youngsters who took an interest in the overview from 29 areas trusted that schools would not give such a large number of tasks and that two-way correspondence among instructors and understudies was felt to be more compelling. (Ade Nasihudin Al Ansori, 2020)

Online learning can be done anywhere and can be done at any time because learning is carried out at home and in the community. Therefore online learning can be carried out properly with adequate facilities such as a stable internet network. The teacher is an important element in boosting the success of online learning by fostering independent learning habits to foster independent character. The current pandemic situation is very meaningful for educators, especially PPKn teachers it is not directly possible for educators to directly develop an independent character in students through independent assignments given by the teacher. Instructors and teachers, as fundamental components in teaching, must embrace an uncommon monstrous turnaround from traditional training, such as eye to eye schooling, to online or distance schooling (Bao, 2020; Basilaia and Kvavadze, 2020), which is supported by sufficient innovative improvements in the current time of mechanical unrest 4.0 (Bao, 2020; Basilaia and Kvavadze, 2020).

\section{Conclusion}

Online learning is learning carried out online, where students carry out the learning process at home. Online learning can also affect the characterization of students, one of which is an independent character. From the results of the research conducted by researchers, it can be concluded that learning at home or online has many obstacles, namely: the internet network is less stable, the lack of parental attention in guiding the children's learning process at home, the lack of adequate facilities for students and educators, and the lack of qualified innovation for an educator in teaching online. In fostering an independent character, the researcher concluded a strong influence in online learning at home because students were accustomed to working independently at home. With various habits carried out by students at home, the independent character is inherent in the students.

\section{References}

[1] Abidah, A., Hidaayatullaah, H. N., Simamora, R. M., Fehabutar, D., \& Mutakinati, L. (2020). The Impact of Covid-19 to Indonesian Education and Its Relation to the Philosophy of " Merdeka Belajar ." Studies in Philosophy of Science and Education, 1(1),38-49. https://doi.org/https://doi.org/10.15408/sjsb s.v7i3.15104

[2] Agustino, L. (2020). Analisis kebijakan penanganan wabah COvid-19: Pengalaman Indonesia. Jurnal Borneo Administrator, 16(2), 2253-270. https://doi.org/10.24258/jba.v16i2.68

[3] Ahidin, U. (2020). Covid 19 dan work from home. Desanta Muliavisitama. Goggle scolar 
[4] Anita Lie, Sarah Prasasti. 2004. Menjadi Orang Tua Bijak, 101 Cara Membina Kemandirian dan Tanggung Jawab Anak. Jakarta: Elex Media Komputindo

[5] Ashari, M. (2020). Proses Pembelajaran Daring di Tengah Antisipasi Penyebaran Virus

[6] Austin, A., S.L. Craig \& Melnroy. L. 2016. Toward transgender affirmative social work education. Journal of social work education 52 (3), 297-310. DOI:https://doi.org/10.1080/10437797.2016.1174637

[7] Corona Dinilai Belum Maksimal. PikiranRakyatcom

[8] Baba, M.M. 2020. Navigation covid-19 with emotional intelligence. International journal of social psychiatry, 1-11. Doi: 10.1177/0020764020934519.

[9] Basilaia, G., \& Kvavadze, D. (2020). Transition to Online Education in Schools during a SARS-CoV-2 Coronavirus (COVID-19) Pandemic in Georgia. Pedagogical Research,5(4). https://doi.org/10.29333/pr/7937

[10] Budiman, Nandang. 2006. Memahami Perkembangan Anak Usia Sekolah Dasar. Jakarta: Departemen Pendidikan Nasional Direktorat Jenderal Pendidikan Tinggi Direktorat Ketenagaan.

[11] Budiyanto, Mangun \& Machali, Imam. (2014). Pembentukan Karakter Mandiri Melalui Pendidikan Agriculture di Pondok Pesantren Islamic Studies Center Aswaja Lintang Songo Piyungan Bantul Yoqyakarta. Jurnal Pendidikan karakter, Tahun IV, Nomor 2. Doi:https://doi.org/10.21831/jpk.v0i2.2784

[12] Chaplin, J.P. (2011). Kamus Lengkap Psikologi. Jakarta: Rajagrafindo Persada

[13] Faura, J.C. 2020. The Role Of Social Work In The Field Of Education During Covid-19. Journal Social Work Vol.63(6) 795-787. DOI:10.1177/0020872820944994

[14] Goldschmidt, K., \& Msn, P. D. (2020). The COVID-19 pandemic: Technology use to support the wellbeing of children. Journal of Pediatric Nursing, $x x x x, 3-5$. https://doi.org/10.1016/i.pedn.2020.04.013

[15] Hidayatullah, Furqon. (2010). Pendidikan Karakter: Membangun Peradaban Bangsa. Surakarta: Yuma Pustaka.

[16] Jossberger, Helen. (2011). Toward Self Regulated Learning in Vocational Education: Difficulties and Opportunities. Heerlen: Universitaire Pers Maastricht

[17] Kurniawan, Syamsul. 2013. Pendidikan Karakter: Konsepsi \& Implementasinya secara Terpadu di Lingkungan Keluarga, Sekolah, Perguruan Tinggi, dan Masyarakat. Yogyakarta: Ar-Ruzz Media.

[18] Kusuma, J. W., \& Hamidah. (2020). Platform Whatsapp Group Dan Webinar Zoom Dalam Pembelajaran Jarak Jauh Pada Masa Pandemik Covid 19. Jurnal Ilmiah Pendidikan Matematika Volume, 5(1). DOI:https://doi.org/10.26877/jipmat.v5i1.5942

[19] Lee, A. (2020). Wuhan novel coronavirus (COVID-19): why global control is challenging? Public Health, January, 19-21. https://doi.org/https://doi.org/10.1016/j.puh e.2020.02.001

[20] Mahapatra, M \& Sharma, P. 2020. Education In Times Of COVIC-19 Pandemic: Academic Stress And Its Psychosocial Impact On Children And Adolescentans In India. International journal of social psychiatry, 1-3. DOI:10.117/0020764020961801

[21] Menteri Pendidikan. (2020). Surat Edaran Nomor 3 Tahun 2020 Tentang Pelaksanaan Pendidikan dalam Masa Darurat CoronaVirus (COVID-19).

[22] Nuswantari, N. (2018). Model Pembelajaran Nilai-Nilai Toleransi Untuk Anak Sekolah Dasar. Premiere Educandum: Jurnal Pendidikan Dasar dan Pembelajaran, 8(1), 41-53. DOI:10.25273/pe.v8i1.2255

[23] Ochmah, E. (2015). Pengaruh Self Regulated Learning, Gaya Belajar, dan Pola Asuh Orangtua terhadap Hasil Belajar Mata Pelajaran Kejuruan se-Kecamatan Weru (Doctoral dissertation, Tesis. Universitas Negeri Yogyakarta, Yogyakarta)

[24] Sun. L., Tnag Y \& Zuo, W. (2020). Corona virus pushed education online. Nature Materials. Https://doi.org/10.1038/s41563-020-0678-8. 
[25] Wibowo, Agus. (2012). Pendidikan Karakter Usia Dini (Strategi Membangun Karakter Usia Dini). Yoqyakarta: Pustaka Belajar.

[26] Wicaksono, V. D., \& Rachmadyanti, P. (2016). Pembelajaran Blended Learning melalui Google Classroom di Sekolah Dasar. Seminar Nasional Pendidikan PGSD UMS \& HDPGSDI Wilayah Timur.

[27] Yurianto, Ahmad, Bambang Wibowo, K. P. (2020). PEDOMAN PE NCEGAHAN DAN PENGENDALIAN CORONAVIRUS DISEASE (COVID-19) (M. I. Listiana Azizah, Adistikah Aqmarina (ed.)).

[28] Zhou. L., Li. F., Wu.S.,\& Zhou, M. (2020). School's Out, but class.s on. The largest online education in the world today: Taking China's practical exploration during the covid-19 epidemic prevention and control as an example. The largest online education in the world today (2),501-519. https://doi.org/10.15354/bece.20.ar023

[29] Zhu, X., \& Liu, J. (2020). Education in and After Covid-19:Immediate Responses and Long- Term Visions. Nature Public Health Emergency Collection, 1-5. DOI:10.1007/s42438-020-00126-3 